\title{
An Empirical Research on Status and Influencing Factors of Global Value Chain Based on GVC Position Index
}

\author{
ZHAO Tong \\ International Business School of Shaanxi Normal University \\ Xi'an, Shaanxi 710119
}

\begin{abstract}
This paper estimates the GVC status index of 20 countries including China from 2000 to 2011 . It is found that the international specialization status in developed countries is higher than that in developing countries, but the former shows a downward trend while the latter shows an upward trend. Using the panel data and fixed effect models to examine influencing factors of the national manufacturing industry, the results show that the increase of natural resource abundance and the supply of government public goods can raise developing countries' specialization status in the global value chain; the $R \& D$ investment can promote the international specialization status of both developed and developing countries.
\end{abstract}

Keywords-Global value chain; Value-added trade; Measurement of GVC position; Influencing factors of GVC position

\section{INTRODUCTION}

With the rise of the global value chain (Global Value Chain, GVC), the pattern of division of labor in the international manufacturing industry has evolved continuously. The mode of participating in international division of labor has gradually changed from specialized producing specific products into specialized production links of specific products; the boundary of division of labor has also changed from different industries to the different value-added take of the same industrial value chain.

The developed countries and developing countries have taken different measures to deal with this new situation of the GVC division. On the one hand, the developed countries such as the United States, Japan and Western Europe, on the basis of the dominant position, further consolidate the high value-added links in $\mathrm{R} \& \mathrm{D}$, design, marketing and brand strategy of product; On the other hand, the developing countries including China, benefit from the transferred labor intensive links such as processing, assembly, outsourcing and logistics from developed countries. However, developing countries play a more important role as executors, and the added value obtained from international division of labor is very limited. Therefore, to understand the objective law that affects the international division of labor is of great practical significance for developing countries to improve their position of the division of labor in the world.

\section{LITERATURE REVIEW}

With the expansion of export trade scale, how to measure the status of a country's global value chain, reflect its real trade gains and the position of division of labor, the scholars mainly adopt three methods: according to the price of export products, the technical content of export products, and the trade in value added.

The research on the factors influencing the division of labor in GVC has only arisen in recent years, and the number of documents is relatively small. From the overall level of the country, Hausmann [1] and other (2007) in the study pointed out that the scale of the country and the human capital have a significant promotion impact on the export complexity of the countries. Liu Haiyun [2] and so on (2015) use panel regression and threshold regression to analyze the factors that affect international division of labor, and find that the level of technological innovation, human capital, supply of public goods and foreign direct investment have significant positive effects on the promotion of international division of labor, but the influence effect of technological innovation level and government efficiency has a decreasing trend.

From the level of domestic manufacturing and subdivision industries, Zhang Kuiliang [3] (2011) has found that R \& D input is the basic factor for China's manufacturing industry to upgrade its global value chain by measuring the panel data of 11 manufacturing industries in China for 14 years. And in the long run, the expansion of the industry scale and the improvement of technological level have a positive impact on the performance of China's manufacturing industry in the global value chain.The results of Ma Fengtao's [4] (2015) study show that labor productivity, R \& D intensity, the relative investment ratio of skilled labor and the ratio of domestic added value to the product will promote the development of the department upper reaches. 


\section{CALCULATION AND INTERNATIONAL COMPARISON OF GVC DIVISION OF LABOR IN DIFFERENT COUNTRIES}

\section{A. Theoretical model}

This paper use the total export decomposition method proposed by Koopman [5], decompose the total export of a country into domestic added value and foreign added value. According to the calculation framework of the value added trade proposed by Koopman and other (2010), a country's position index of division of labor in the global value chain is as follows:

$$
G V C_{-} \text {Position }_{q}=\operatorname{Ln}\left(1+\frac{I V_{i}}{E_{i}}\right)-\operatorname{Ln}\left(1+\frac{F V_{i}}{E_{i}}\right)
$$

Among them, $I V_{i}$ indicates the domestic indirect added value contained in the total export of state $\mathrm{i} ; F V_{i}$ express the foreign added value contained in the total export of state $\mathrm{i} ; E_{i}$ shows the total export accounted by value added. $\frac{I V_{i}}{E_{i}}$ indicates forward participation index; $\frac{F V_{i}}{E_{i}}$ indicates backwards participation index. The larger (smaller) the GVC index is, the closer the international division of labor is to the upper (lower) link of the global value chain.

\section{B. GVC status index of manufacturing industry in various countries}

In this paper, the value added trade database (TiVA), first published by WTO and OECD in 2013, is used as the data source. Table 1 is the calculation of the GVC status index of the top 20 developing countries and developed countries in 2000-2011 years. The order of the group is ranked from high to low by the international division of labor in 2011. In the developing countries, Brazil has the highest international division of labor status, followed by Argentina and Russia, the lowest position is Thailand, and China is second to the sixth ranking India, in the back position. In the GVC status index of 2011, the indirect domestic added value (IV) of Brazil, Argentina, Russia and Indonesia was significantly higher than their foreign value added in export (FV), indicating that they were in the favorable position of international division of labor. The domestic added value of Turkey was slightly higher than that of foreign value added, and the domestic added value of India and China is basically equal to the foreign value added, while the foreign added value in the export of Mexico, South Korea and Thailand is obviously higher than the domestic added value, which is relatively in the lower link of the global value chain.

In developed countries, Japan, Australia, the United States, France and Italy have a higher international division of labor status, which are in the upper link of the value chain, and tend to transport intermediates to other countries. However, the highest ranking GVC status index of Japan is only 0.182 , even lower than Brazil, Russia and other developing countries. The lowest ranking of Holland's domestic added value is only slightly less than its foreign value added, indicating that the GVC position index of developed countries is more concentrated and the gap among these countries is not large.

TABLE I 2000-2011 years' Manufacturing GVC status index

\begin{tabular}{|c|c|c|c|c|c|c|c|c|c|c|c|c|}
\hline Country/Year & 2000 & 2001 & 2002 & 2003 & 2004 & 2005 & 2006 & 2007 & 2008 & 2009 & 2010 & 2011 \\
\hline Brazil & 0.288 & 0.252 & 0.265 & 0.277 & 0.279 & 0.305 & 0.297 & 0.303 & 0.285 & 0.317 & 0.316 & 0.323 \\
\hline Argentina & 0.364 & 0.328 & 0.357 & 0.311 & 0.263 & 0.241 & 0.238 & 0.248 & 0.217 & 0.277 & 0.251 & 0.237 \\
\hline Russia & 0.108 & 0.139 & 0.147 & 0.151 & 0.179 & 0.193 & 0.189 & 0.202 & 0.192 & 0.229 & 0.228 & 0.205 \\
\hline Indonesia & 0.092 & 0.094 & 0.133 & 0.141 & 0.103 & 0.105 & 0.120 & 0.140 & 0.118 & 0.190 & 0.188 & 0.163 \\
\hline Turkey & 0.111 & 0.071 & 0.087 & 0.081 & 0.067 & 0.106 & 0.074 & 0.071 & 0.056 & 0.104 & 0.075 & 0.029 \\
\hline India & 0.285 & 0.259 & 0.257 & 0.237 & 0.189 & 0.150 & 0.108 & 0.114 & 0.039 & 0.084 & 0.049 & 0.016 \\
\hline China & -0.170 & -0.171 & -0.188 & -0.200 & -0.170 & -0.139 & -0.104 & -0.058 & -0.015 & -0.001 & -0.020 & -0.019 \\
\hline Mexico & -0.136 & -0.112 & -0.099 & -0.124 & -0.136 & -0.121 & -0.131 & -0.136 & -0.131 & -0.130 & -0.140 & -0.111 \\
\hline Korea & -0.042 & -0.016 & 0.004 & -0.046 & -0.071 & -0.068 & -0.084 & -0.101 & -0.180 & -0.120 & -0.135 & -0.164 \\
\hline Thailand & -0.089 & -0.102 & -0.097 & -0.095 & -0.127 & -0.142 & -0.139 & -0.135 & -0.179 & -0.111 & -0.143 & -0.188 \\
\hline Japan & 0.287 & 0.290 & 0.281 & 0.275 & 0.261 & 0.229 & 0.201 & 0.183 & 0.175 & 0.233 & 0.200 & 0.182 \\
\hline Australia & 0.183 & 0.205 & 0.175 & 0.219 & 0.229 & 0.225 & 0.216 & 0.206 & 0.175 & 0.197 & 0.185 & 0.146 \\
\hline USA & 0.171 & 0.198 & 0.191 & 0.183 & 0.161 & 0.156 & 0.139 & 0.143 & 0.125 & 0.165 & 0.140 & 0.118 \\
\hline France & 0.062 & 0.076 & 0.083 & 0.097 & 0.084 & 0.064 & 0.045 & 0.040 & 0.055 & 0.095 & 0.068 & 0.052 \\
\hline Italy & 0.128 & 0.135 & 0.144 & 0.145 & 0.128 & 0.102 & 0.066 & 0.057 & 0.053 & 0.111 & 0.057 & 0.040 \\
\hline German & 0.101 & 0.105 & 0.113 & 0.109 & 0.100 & 0.077 & 0.045 & 0.037 & 0.028 & 0.066 & 0.033 & -0.008 \\
\hline Spanish & -0.008 & 0.006 & 0.018 & 0.017 & -0.001 & -0.008 & -0.042 & -0.048 & -0.026 & 0.038 & 0.002 & -0.035 \\
\hline Canada & -0.059 & -0.030 & -0.027 & 0.003 & -0.010 & -0.010 & 0.005 & 0.004 & -0.032 & -0.013 & -0.035 & -0.040 \\
\hline UK & 0.076 & 0.076 & 0.086 & 0.090 & 0.075 & 0.071 & 0.062 & 0.049 & 0.015 & 0.027 & -0.015 & -0.047 \\
\hline Netherlands & -0.050 & -0.020 & -0.012 & -0.007 & -0.024 & -0.033 & -0.052 & -0.050 & -0.063 & -0.031 & -0.069 & -0.093 \\
\hline
\end{tabular}

In general, the GVC index in developed countries is generally higher than that in developing countries, and relatively stable. But other developed countries, except for Australia and Spain, have a downward trend. In the developing countries, the GVC status index of Brazil, Russia, China and Indonesia has been rising obviously, and their international status have been promoted, which reflects the trend of the following countries. Among the top developing countries in 
the international division of labor, the common characteristics of abundant natural resources except Turkey and India have an important impact on the GVC division of labor in the manufacturing industry. In China, Mexico, South Korea and Thailand, where the international division of labor is low-ranked, the export of processing trade accounts for a large proportion of the total export, and the low value-added services such as assembly processing and outsourcing are more developed, which shows that the progress of $\mathrm{R} \& \mathrm{D}$ technical ability has a positive effect on the improvement of the international division of labor status.

\section{EMPIRICAL ANALYSIS OF THE FACTORS AFFECTING THE GVC DIVISION OF LABOR}

\section{A. Model setting and data description}

1) Model establishment and index selection

On the basis of the traditional comparative advantage theory and the dynamic comparative advantage theory, and drawing on the research methods in the classical literature, this paper selects the natural resource abundance, factor endowment of human capital, R \& D input, government expenditure, foreign direct investment and scale economy as the explanatory variables. The concrete models are established as follows:

$$
\begin{aligned}
& \text { GVC_Position }_{t t}=c+\beta_{1} \text { resource }_{i t}+\beta_{2}\left(\frac{K}{L}\right)_{i t}+\beta_{3} R D_{i t}+\beta_{4} \text { government }_{t t}+ \\
& \beta_{5} F D I_{i t}+\beta_{6} \text { scale }_{i t}+\alpha_{i}+\varepsilon_{i t}
\end{aligned}
$$

Among them, as an explanatory variable, $G_{\text {G }}$ Position $_{t \text { it }}$ indicates the division position index of country $i$ in the global value chain in the period of $t$.

resource represents the index of natural resources, shows the original factor endowment of a country. This paper uses the proportion of primary resource exports to total exports to measure the impact of natural resource abundance on the status of international division of labor.

$\left(\frac{K}{L}\right)_{i t}$ As another resource endowment, human capital is one of the important factors influencing the status of international division of labor. This article uses the ratio of capital to labor to reflect the result of a country's factor endowment.

$R \& D_{i t}$ uses the proportion of investment in GDP to represent the research and innovation level of country $i$ in $t$ era, reflecting the endogenous technological progress of a country.

government represents the quantity of public goods invested by government, it is measured by the proportion of the governmental total consumption to the total GDP.

The foreign indirect investment is measured by the ratio of FDI capital stock to GDP of country $i$ in period t. By introducing foreign investment, a country can increase the export of technology intensive and capital intensive industries. At the same time, the technology spillover effect can be used to enhance the innovation ability, so as to improve the division of labor status of GVC.

scale $_{i t}$ This index indicates the scale economy level of country $\mathrm{i}$ in the $\mathrm{t}$ period, and its export market share is measured by the proportion of the total exports of a country to the world's total exports.

\section{2) Data sources and description}

This paper select panel datas from 20 countries in the developed countries and the developing countries in 2000-2011 years as research objects for regression analysis. Data are derived from the TiVA database, the world development index (WDI) database and the United Nations Conference on Trade and Development (UNCTAD) database.

\section{B. Empirical test and regression analysis}

In this paper, the panel fixed effect model is used to analyze the influencing factors of GVC division of labor in different countries. The following inference can be made from the data in Table 2:

TABLE II Regression results of factors affecting the GVC division of labor in state's manufacturing sector

\begin{tabular}{|l|l|l|l|l|}
\hline \multicolumn{4}{|l|}{} & \multicolumn{3}{l|}{ Developing countries } & Developed countries \\
\hline Variable & Coefficient & Prob & Coefficient & Prob \\
\hline c & -0.085625 & 0.0878 & 0.369094 & 0.0000 \\
\hline resource & 0.691249 & 0.0000 & 0.002625 & 0.9737 \\
\hline K/L & $-1.63 \mathrm{E}-05$ & 0.0014 & $-1.28 \mathrm{E}-06$ & 0.3902 \\
\hline R\&D & 0.052960 & 0.0596 & 0.083713 & 0.0000 \\
\hline government & 0.013557 & 0.0018 & -0.019093 & 0.0000 \\
\hline FDI & -0.022557 & 0.0307 & -0.009078 & 0.0001 \\
\hline scale & -2.807411 & 0.0000 & -1.010722 & 0.0055 \\
\hline
\end{tabular}

The impact of the natural resource abundance index of developing countries on GVC division status is positive, and its estimation coefficient is 0.69 , indicating that developing countries are more dependent on the rich natural resources in the international division of labor, and are more inclined to 
export the intermediate goods of natural resources intensive products.

Capital labor index is also only passed significant test in developing countries, which has a negative impact on the international division of labor in developing countries, but the impact is very small. It shows that the promotion of international division of labor needs long-term accumulation, while paying attention to the importance of capital, it is necessary to improve the quality of the labor force and pay more attention to the ability of technological innovation.

The estimation coefficient of $\mathrm{R} \& \mathrm{D}$ input index of developing and developed countries is significantly positive at the level of $10 \%$ and $1 \%$. It shows that both developing and developed countries can improve the international division status of the manufacturing industry by increasing the investment in research and development and improving the ability of independent innovation.

The government's final consumption index in developing countries is positively related to the international division of labor, indicating that the more public goods is provided by the government, the more it can drive the developing countries' manufacturing industry to various links in the GVC, and the higher the division of labor status in the global value chain it be.

The variation coefficient of FDI indicators is significantly negative in both developing and developed countries. This may be due to the transformation and upgrading of the manufacturing industry in various countries, and the technological and marketing advantages of foreign direct investment to the industry have gradually weakened, which in essence can not play a role in promoting the value chain position of the division of labor.

There is a significant negative correlation between the scale economy indicators and the division status of the GVC, indicating that the increase in the export market share of the developing and developed countries does not promote the international division of labor status.

\section{CONCLUSION}

Based on the accounting method of value added trade, this paper estimates the global value chain division status index of the top 20 developing countries and developed countries in 2000-2011 years. It is found that among the GVC status index in top 10 developing countries, most countries are with rich natural resources. And the overall level of GVC index in developed countries is higher than that of developing countries, but the growth rate of developing countries' status index is faster than that of developed countries.

The fixed effect regression analysis of panel data of 20 countries is conducted to verify the factors affecting the division of labor in the global value chain. The results show that $\mathrm{R} \& \mathrm{D}$ input has a positive effect on promoting the international status of the manufacturing sector in both developed and developing countries. The influence of technological advantage and marketing advantage of foreign direct investment on industry is gradually weak. In essence, it can not play a role in upgrading the value chain of labor division. The abundance of natural resources and governmental expenditure on public goods is mainly to increase the supply of natural resource intensive intermediate goods in developing countries, thus promoting its status in the global value chain.

In view of our country's reality, in order to realize the rapid promotion of the division of labor in the global value chain, we should not only make full use of the advantages of abundant natural resources and pay more attention to the accumulation of human capital, but also need to increase the investment in $\mathrm{R}$ \& D innovation, increase the government's expenditure on public goods, and increase the investment by foreign investment. The high quality of capital will reverse the negative effect of foreign investment on the division of labor in China, and enter the stage of high economic quality development as soon as possible.

\section{REFERENCES}

[1] Hausmann et al. What You Export Matters[J]. Journal of Economic Growth, 2007(12):1-25.

[2] Liu Haiyun, Mao Haiou. The status and its influencing factors of the international division of labor -- Based on the empirical analysis of "GVC status index" [J]. International economic and trade exploration,2015,31(08):44-53.(In Chinese)

[3] Zhang Kuiliang. The measurement and improvement strategy of China's manufacturing industry in the global value chain [J]. Market modernization,2010(08):9-10.(In Chinese)

[4] Ma Fengtao. Measurement and analysis of its influencing factors of the length and upstream degree of the global value chain in China's manufacturing industry - based on the world input-output table [J]. World economic research, 2015 (08): 3-10+127.(In Chinese)

[5] Koopman, R. et al. 2010. Give Credit to Where Credit is Due: Tracing Value Added in Global Production [J]. NBER Working Paper 16426.

[6] Fontagne et al.Specialization across Varieties within Products and North-South Competition. CEPTT Working Paper,1987:2007-06.

[7] Hu Zhaoling, Song Jia. Research on the status of China's international division of labor based on export prices [J]. International trade issues, 2013 (3): 15-25.(In Chinese)

[8] Ju Jiandong, Yu Xinding. The role of China in the global value chain: Based on China's industrial upstream and customs data research [J]. Nankai economic research, 2014 (3): 39-52.(In Chinese)

[9] Li Xiaohua. The pattern of international industrial division of labor and the development trend of division of labor in China [J]. International economic and trade exploration, 2015,31 (06): 4-17.(In Chinese)

[10] Wang Lan. The impact of integrating into the global value chain on the status of international division of labor in China's manufacturing industry [J]. Statistical research, 2014,31 (05): 17-23.(In Chinese) 